\title{
A STUDY ON CHRONIC OBSTRUCTIVE PULMONARY DISEASE (COPD) PATIENTS WITH REFERENCE TO ECHOCARDIOGRAPHIC FINDINGS
}

\author{
Uma Sankar Kutum ${ }^{1}$, Dipankar Deb2 ${ }^{2}$ Prabhash Chandra Sarma ${ }^{3}$, Tanushree Deb ${ }^{4}$, Ravikumar Pujar 5 \\ ${ }_{1}^{1}$ Registrar, Department of General Medicine, Tezpur Medical College, Tezpur. \\ ${ }^{2}$ Associate Professor, Department of General Medicine, Silchar Medical College, Silchar. \\ 3 Professor \& HOD, Department of Cardiology, Silchar Medical College, Silchar. \\ ${ }^{4}$ Resident Physician, Department of General Medicine, Silchar Medical College, Silchar. \\ ${ }^{5} 3^{\text {rd }}$ Year PGT Department of General Medicine, Silchar Medical College, Silchar.
}

ABSTRACT
BACKGROUND
Chronic Obstructive Pulmonary Disease (COPD) is a common and preventable disease, which has great implication on global
health. It is acknowledged by WHO as a commonest cause of death worldwide. The major morbidity of COPD is due to its impact on
cardiac performance. Right ventricular dysfunction is common in patients with COPD. Echocardiogram is a very simple and
convenient bedside investigation to detect cardiac function and structure.

\section{OBJECTIVE}

To study the clinical profile, echocardiographic findings of COPD patients and to correlate the echocardiographic findings with the severity of the disease.

\section{MATERIAL METHOD}

A total of 100 patients admitted in the Department of Medicine of Silchar Medical College during the period from June 2013 to May 2014 were selected and detailed clinical examination, pulmonary funtion test, Chest X-Ray, ECG and Echocardiogram were done in all cases.

\section{RESULT}

Mean age of the patients was $61+8.6$ years and highest $46 \%$ were in the age group of 61 to 70 years and $86 \%$ were male. Highest number $64 \%$ were farmers residing in rural area (83\%); $89 \%$ of patients were smoker presented with cough (97\%), expectoration of sputum (93\%) and dyspnoea (91\%). The patient had pedal oedema (65\%), raised JVP (56\%) and cynosis (43\%). In 94\% pulmonary rales, $79 \%$ use of accessory muscle of respiration, $74 \%$ ronchi and $52 \%$ barrel shaped chest was found. In chest X-ray 49\% had chronic bronchitis and another 49\% emphysema. Pulmonary function test revealed severe obstruction in 50\% and moderate obstruction in 46\%. ECG revealed P-Pulmonale (51\%), Right axis deviation (45\%), RVH (39\%) and RBBB (31\%). Echocardiogram shows dilated right ventricle (53\%), Pulmonary hypertension (53\%), right atrial enlargement (42\%) and right ventricular hypertrophy (26\%). In the moderate severe COPD 32.60\% (15 out of 46) had dilatation of right ventricle and pulmonary hypertension. Only $8.69 \%$ had right atrial enlargement. In severe group $76 \%$ had right atrial enlargement, dilated right ventricle and pulmonary hypertension. Right ventricular hypertrophy was present in 52\%.

\section{CONCLUSION}

From the present study, it is concluded that COPD is common in male smoker with rural background in the age group 61 to 70 years age. Main presenting features are chronic cough with expectoration with pedal oedema and raised JVP. Equal no. of patients belonged to chronic bronchitis and emphysema. Right side of heart is affected commonly as detected by ECG and Echocardiography. Echocardiography plays an important role in detecting involvement of right side of heart in chronic obstructive pulmonary disease.

\section{KEYWORDS}

Spirometry, Electocardiogram, Echocardiogram.

HOW TO CITE THIS ARTICLE: Kutum US, Deb D, Sarma PC, et al. "A study on chronic obstructive pulmonary disease (COPD) patients with reference to echocardiographic findings." Journal of Evolution of Medical and Dental Sciences 2015; Vol. 4, Issue 103, December 24; Page: 16814-16821, DOI: 10.14260/jemds/2015/2524

\section{INTRODUCTION}

Chronic Obstructive Pulmonary Disease (COPD) is a common and preventable disease, which has great implications on global health. It is acknowledged by the "WHO" as the fourth commonest cause of death worldwide, exceeded only by myocardial infarction, malignancy and stroke.

Financial or Other, Competing Interest: None.

Submission 21-11-2015, Peer Review 23-11-2015,

Acceptance 18-12-2015, Published 22-12-2015.

Corresponding Author:

Dr. Dipankar Deb,

Associate Professor,

Department of General Medicine,

Silchar Medical College,

Silchar-788014.

E-mail: dr.dipankardebcardio@gmail.com

DOI:10.14260/jemds/2015/2524
By 2030, it is expected to rise to the $3^{\text {rd }}$ position as a cause of death. ${ }^{1}$

Right Ventricular (RV) dysfunction is common in patients with COPD, particularly in those with low oxygen saturation. It occurs in upto $50 \%$ of the patients with moderate-to-severe COPD. ${ }^{2}$ When present it can reduce exercise tolerance, increased dyspnoea and contribute to an overall decrease in functional status and portends a higher mortality rate. Its recognition and treatment may lead to prolonged survival and improved quality of life.

Since the echocardiogram is a very simple and bedside investigation to detect early changes in the cardiac function and structure. In this study an effort is made to study echocardiographic changes in chronic obstructive pulmonary 
disease patients and correlate it with severity of the disease as assessed clinically and through pulmonary function testing.

\section{AIMS AND OBJECTIVES}

1. To study the clinical profile of Chronic Obstructive Pulmonary Disease (COPD) patients.

2. To study the echocardiographic findings in Chronic Obstructive Pulmonary Disease (COPD) patients.

3. To correlate echocardiographic findings with the severity of the disease.

\section{Review of Literature}

Hypertrophy and functional abnormalities of the right ventricle resulting from long-standing pulmonary disease have been well documented. ${ }^{3}$ In 1975 Stephen and Richard showed that pulmonary artery pressure and pulmonary vascular resistance could be evaluated by echocardiographic assessment and thus reduced necessity for repeated cardiac catheterization. ${ }^{4}$

In 1982, Tomi Watanabe et al. ${ }^{5}$ evaluated applicability of 2-dimensional echocardiography to right ventricular volume determination and compared it with angiocardiographic measurements and concluded that estimation of right ventricular volume and morphology with 2-D echocardiography is an excellent non-invasive method available in clinical practice to evaluate right ventricular volume and morphology.

In 1982, Starting and Crawford et al. ${ }^{6}$ described a new 2dimensional echo technique for evaluating right ventricular size and performance in patients with COPD.

In 1987, Oswald Mammosser et al. ${ }^{7}$ in their study comparing ECG, radiological measurements, echocardiography and myocardial scintigraphy for their respective values in diagnosis of pulmonary arterial hypertension in COPD patients using right heart catheterization as the reference method and found that echocardiography had the best results.

Himelman et al. in 1988 in their study in patients with severe chronic obstructive pulmonary disease found 55\% patients had RV dilatation, $49 \%$ had pulmonary hypertension, $39 \%$ had RA enlargement and 25\% had RV hypertrophy. 8

\section{MATERIALS AND METHODS}

The present study was conducted in the Department of Medicine, Silchar Medical College and Hospital, Silchar, Assam. It is situated in the Cachar District of the Barak Valley in the State of Assam, India. The Barak Valley consists of Cachar, Hailakandi, Karimganj and Dima Hasao districts. It is the tertiary and referral centre for the patients of the different districts of the Barak Valley of Assam and nearby NorthEastern states like Tripura, Mizoram, Manipur, Meghalaya and Nagaland.

\section{Period of Study}

The present study was conducted from June 2013 to May 2014 for a period of one year.

\section{Study Design}

The present study is a hospital based observational study.

\section{DATA COLLECTION}

\section{Inclusion Criteria}

The patients who were admitted in the medical wards with symptoms suggestive of airway obstruction of more than 2 years' duration and in whom clinical diagnosis of chronic obstructive pulmonary disease was made. All these patients were subjected to spirometric test; the patients with forced expiratory volume in first second (FEV1) of less than $80 \%$ of the expected value, which does not alter significantly after bronchodilator inhalation $(<200 \mathrm{ml})$ were included in the study.

Sample size: The total number of patients included in the present study was 100 .

\section{Exclusion Criteria}

Patients with Bronchial asthma, Pulmonary tuberculosis, Bronchiectasis, known congenital or acquired heart diseases, Diabetes mellitus and Hypertension were excluded from the present study.

\section{Study Variables}

\section{The different study variables that were evaluated}

1. Demographic and socioeconomic variables like age, sex occupation, place of living, smoking status.

2. History of presenting symptoms and any history of similar illness in the past.

3. General examination like pallor, pulse, blood pressure, cynosis, JVP, pedal oedema and systemic examination findings of all the systems were noted carefully.

4. Investigations like complete blood count, random blood sugar, chest X-ray, pulmonary function test, electrocardiography and echocardiography were done in all patients.

\section{STATISTICAL METHODS}

Descriptive statistical analysis has been carried out in the present study. Results on continuous measurements are presented on Mean \pm SD (Standard Deviation) and results on categorical measurements are presented in Number (\%) Significance is assessed at $1 \%$ level of significance. Chisquare/Fisher Exact test has been used to find the significance of study parameters on categorical scale between two or more groups.

\section{Details of Methodology and Investigations used Pulmonary Function Test}

All cases were subjected for pulmonary function test using computerized spirometer and evaluated for:-

- Forced expiratory volume in one second (FEV1).

- Forced vital capacity (FVC).

- Ratio of FEV1/FVC.

\section{Bronchodilator Reversibility Testing}

The subject was asked to abstain overnight from oral and

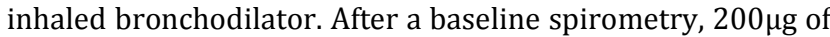
inhaled salbutamol was administered via a metered dose inhaler and the test was repeated after 15 minutes. As per guidelines, an increase in FEV1 that is greater than $200 \mathrm{ml}$ and/or $12 \%$ above the pre-bronchodilator FEV1 were excluded from the study. 


\section{Radiological Findings}

A chest X-ray PA view was taken in all patients and the following points were noted:

1. Evidence of emphysema.

2. Evidence of chronic bronchitis.

\section{Electrocardiographic Examination}

A 12-lead ECG was taken in all the patients under study and the following points were noted:

1. 'P' wave changes - 'P' pulmonale, 2. RVH, 3. Low voltage complexes, 4. RBBB (rSr/rSR' in V1) QRS $\leq 0.12 \mathrm{sec}, 5$. Right axis deviations.

\section{Echocardiography}

All patients were subjected to echocardiographic examination including 2-D, M-mode and colour Doppler echocardiography to note the presence of pulmonary hypertension, right ventricular hypertrophy, right ventricular dilatation and right ventricular failure.

\section{The following points were noted}

1. Pulmonary hypertension (PASP $>30 \mathrm{~mm}$ of $\mathrm{Hg}$ ).

2. Right ventricular dilatation. (Right ventricular diastolic dimension $>25 \mathrm{~mm}$.

3. Right ventricular hypertrophy. (Thickness of RV anterior wall $>6 \mathrm{~mm}$ ).

4. Right atrial enlargement. (Right atrial dimension $>3.6 \mathrm{~cm}$ ).

All the patients were also subjected to other routine investigations:

1. Hb\% Total count, Differential count, ESR.

2. Urine albumin, sugar, microscopy.

3. Sputum for acid fast bacilli and gram stain.

4. Random blood sugar, blood urea, serum creatinine.

\section{RESULTS AND OBSERVATIONS}

The results and observations are incorporated in the following tables and diagrams and also discussed below:

\section{AGE DISTRIBUTION}

\begin{tabular}{|c|c|c|}
\hline Age in years & Number of Patients & Percentage (\%) \\
\hline $41-50$ & 13 & $13.0 \%$ \\
\hline $51-60$ & 33 & $33.0 \%$ \\
\hline $61-70$ & 46 & $46.0 \%$ \\
\hline $71-80$ & 6 & $6.0 \%$ \\
\hline $81-90$ & 2 & $2.0 \%$ \\
\hline Total & $\mathbf{1 0 0}$ & $\mathbf{1 0 0} \%$ \\
\hline \multicolumn{2}{|c|}{ Table 1: Age Distribution of Patients } \\
\hline
\end{tabular}

Mean \pm SD: $61.84 \pm 8.63$

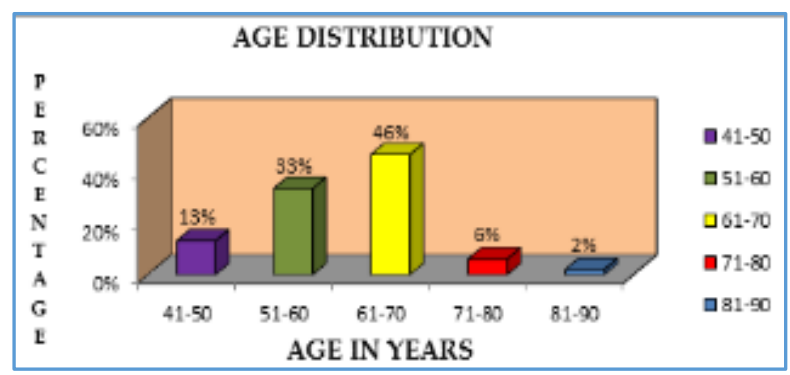

Graph 1: Age Distribution

Mean age of the studied patients was $61.84 \pm 8.63$ years, minimum age being 45 years and maximum age being 81 years. Majority of patients were in the age group 51-70 years constituting $79 \%$.

\section{SEX DISTRIBUTION}

\begin{tabular}{|c|c|c|}
\hline Gender & Number of Patients & Percentage (\%) \\
\hline Male & 86 & $86.00 \%$ \\
\hline Female & 14 & $14.00 \%$ \\
\hline Total & $\mathbf{1 0 0}$ & $\mathbf{1 0 0 . 0 0 \%}$ \\
\hline \multicolumn{2}{|c|}{ Table 2: Sex Distribution of Patients studied } \\
\hline
\end{tabular}

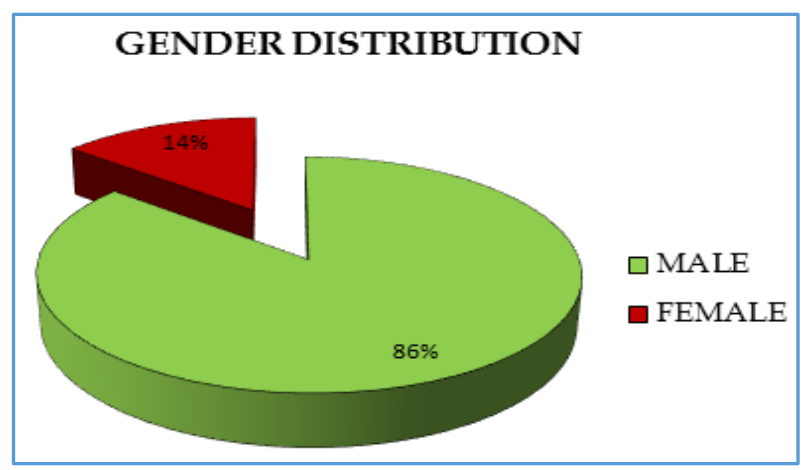

Graph 2: Sex Distribution

Out of 100 patients studied, 86(86\%) patients were male and $14(14 \%)$ patients were females.

\section{Occupational distribution of patients}

\begin{tabular}{|c|c|c|}
\hline Occupation & Number of Patients & Percentage (\%) \\
\hline Farmer & 64 & $64.00 \%$ \\
\hline Housewife & 10 & $10.00 \%$ \\
\hline Worker & 24 & $24.00 \%$ \\
\hline Driver & 2 & $2.00 \%$ \\
\hline Total & 100 & $100.0 \%$ \\
\hline \multicolumn{2}{|c|}{ Table 3: Occupation Distribution of Patients studied } \\
\hline
\end{tabular}

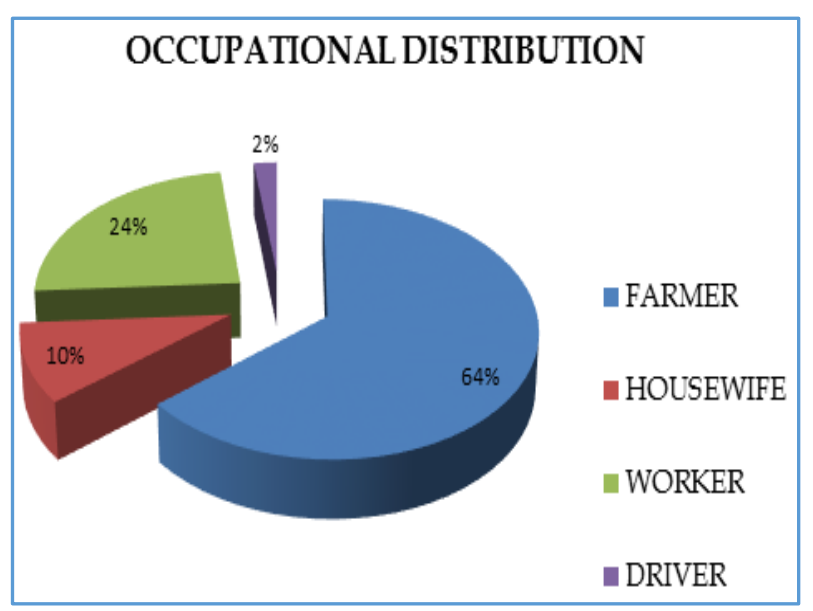

Graph 3: Occupational Distribution

In the present study, majority of the patients in the cases studied were farmers constituting 64\%.

\section{Place of Living}

\begin{tabular}{|c|c|c|}
\hline Place of Living & Number of Patients & Percentage (\%) \\
\hline Rural & 83 & $83.00 \%$ \\
\hline Urban & 17 & $17.00 \%$ \\
\hline Total & $\mathbf{1 0 0}$ & $\mathbf{1 0 0 . 0 0 \%}$ \\
\hline \multicolumn{3}{|c|}{ Table 4: Place of Living } \\
\hline
\end{tabular}




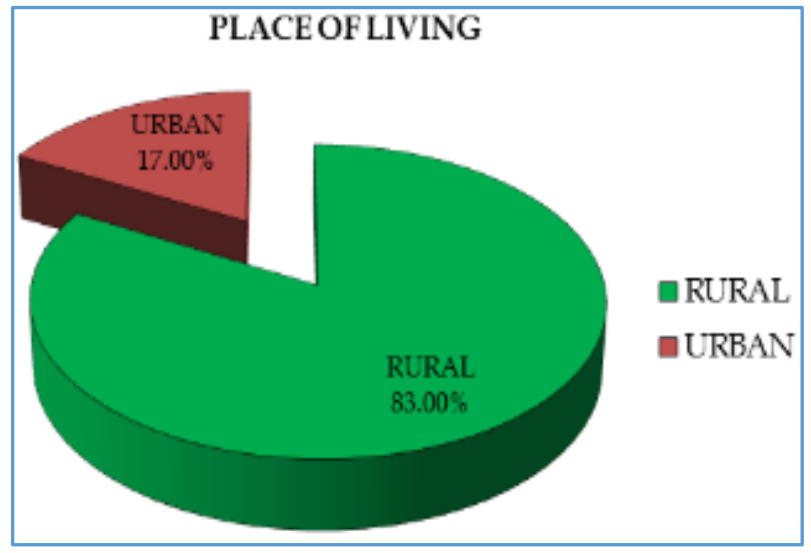

Graph 4: Place of Living

Out of 100 patients, 83(83\%) patients were living in rural area and $17(17 \%)$ in urban area.

\section{Clinical Symptoms}

\begin{tabular}{|c|c|c|}
\hline $\begin{array}{c}\text { Clinical } \\
\text { Symptoms }\end{array}$ & $\begin{array}{c}\text { Number of } \\
\text { Patients }\end{array}$ & $\begin{array}{c}\text { Percentage } \\
\text { (\%) }\end{array}$ \\
\hline Cough & 97 & $97.00 \%$ \\
\hline Expectoration & 93 & $93.00 \%$ \\
\hline Dyspnoea & 91 & $91.00 \%$ \\
\hline Swelling of limbs & 65 & $65.00 \%$ \\
\hline Fever & 63 & $63.00 \%$ \\
\hline Weight loss & 13 & $13.00 \%$ \\
\hline Chest pain & 11 & $11.00 \%$ \\
\hline \multicolumn{2}{|c|}{ Table 5: Clinical Symptoms } \\
\hline \multicolumn{2}{|c}{}
\end{tabular}

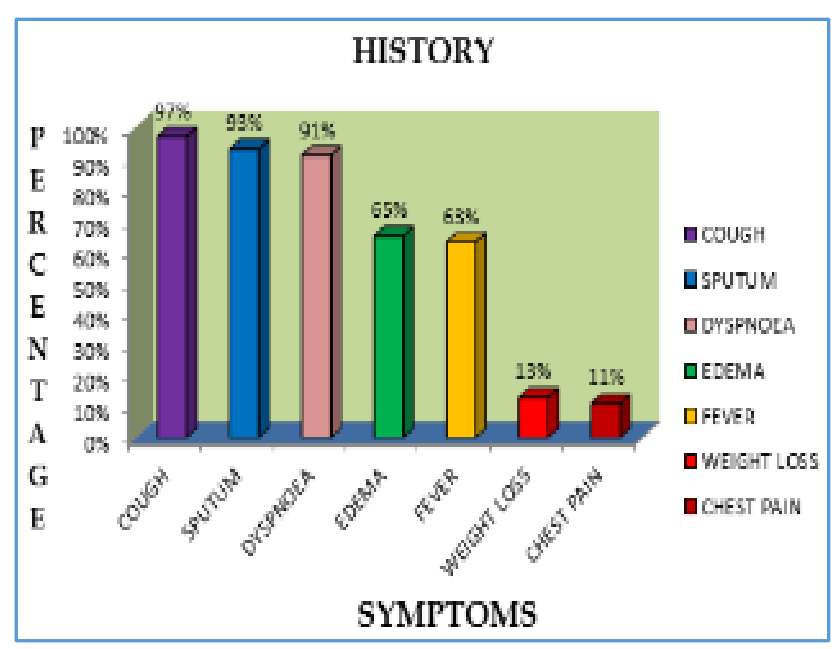

Graph 5: Clinical Symptoms

Cough was present in $97 \%$ of patients, sputum production in $93 \%$ of patients, breathlessness or dyspnoea in $91 \%$ of patients and swelling of lower limbs in $65 \%$ of patients.

\section{Smoking Status}

\begin{tabular}{|c|c|c|}
\hline $\begin{array}{c}\text { Smoking } \\
\text { Status }\end{array}$ & $\begin{array}{c}\text { Number of } \\
\text { Patients }\end{array}$ & $\begin{array}{c}\text { Percentage } \\
\text { (\%) }\end{array}$ \\
\hline Present & 89 & $89.00 \%$ \\
\hline Absent & 11 & $11.00 \%$ \\
\hline Total & 100 & $100.00 \%$ \\
\hline \multicolumn{3}{|c|}{ Table 6: Smoking Status } \\
\hline
\end{tabular}

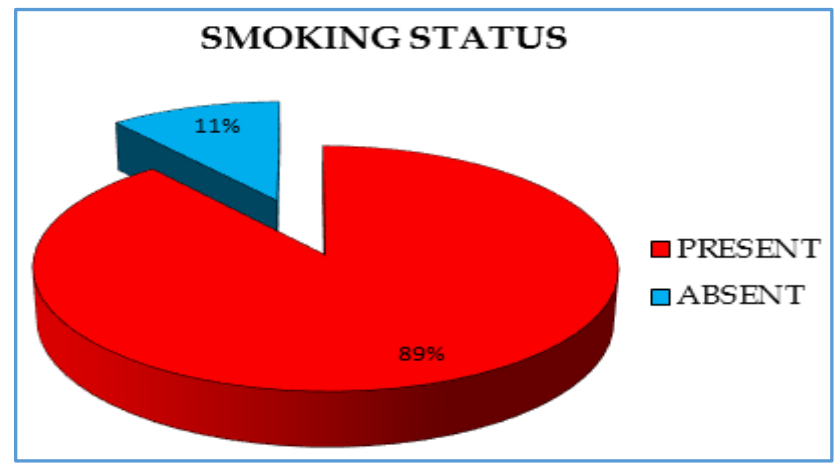

Graph 6: Smoking Status

Among 100 patients, $89 \%$ of patients were smokers and $11 \%$ were non-smokers.

\section{Clinical Findings}

Of the 100 patients studied, mean Systolic Blood Pressure (SBP) was 127.24 \pm 12.60 and mean Diastolic Blood Pressure (DBP) was $77.24 \pm 6.64 \mathrm{mmHg}$.

Mean pulse rate in 100 patients studied was $87.58 \pm 8.86$ beats/minute.

\begin{tabular}{|c|c|c|}
\hline $\begin{array}{c}\text { Clinical } \\
\text { Examination }\end{array}$ & $\begin{array}{c}\text { Number of } \\
\text { Patients }\end{array}$ & $\begin{array}{c}\text { Percentage } \\
\text { (\%) }\end{array}$ \\
\hline Pallor & & \\
\hline •Present & 35 & $35 \%$ \\
\hline$\bullet$ Absent & 65 & $65 \%$ \\
\hline Cyanosis & & \\
\hline •Present & 43 & $43 \%$ \\
\hline • Absent & 57 & $57 \%$ \\
\hline JVP & & $56 \%$ \\
\hline •Raised & 56 & $44 \%$ \\
\hline •Normal & 44 & $65 \%$ \\
\hline Pedal Edema & & $35 \%$ \\
\hline •Present & 65 & \\
\hline • Absent & 35 & \\
\hline \multicolumn{2}{|c|}{ Table 7: General Physical Examination } \\
\hline
\end{tabular}

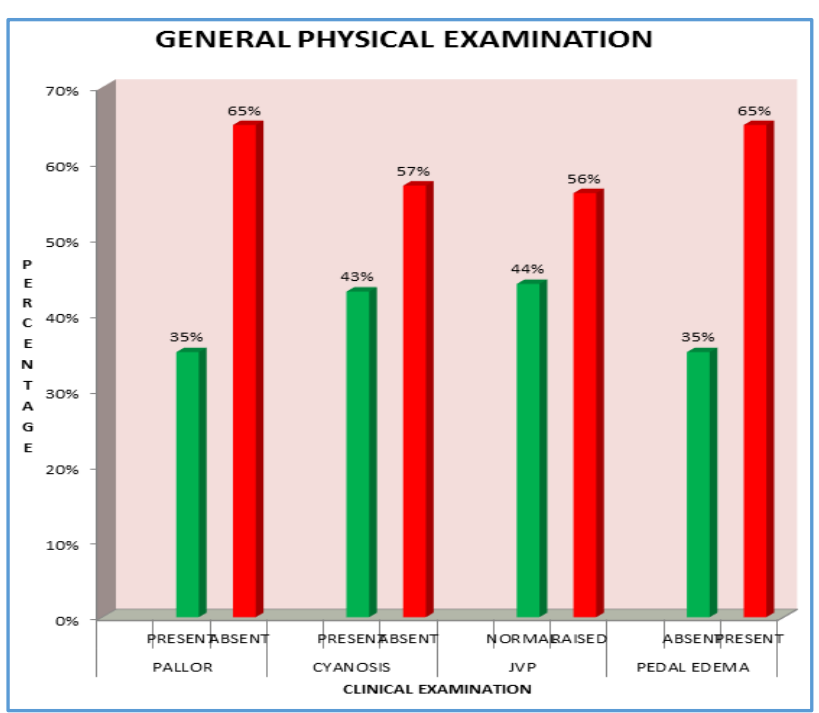

Graph 7: General Physical Examination

Among 100 patients studied, pallor was present in 35\% patients, cyanosis was present in $43 \%$ patients, JVP was raised in $56 \%$ patients and pedal oedema was present in $65 \%$ patients. 
8. Systemic Examination Findings

Chest expansion, Mean \pm SD: $2.5 \pm 0.51$.

\begin{tabular}{|c|c|c|}
\hline Systemic Examination & $\begin{array}{c}\text { Number of } \\
\text { Patients }\end{array}$ & $\begin{array}{c}\text { Percentage } \\
\text { (\%) }\end{array}$ \\
\hline Respiratory system & & \\
\hline Use of accessory muscles & 79 & $79 \%$ \\
\hline Barrel shaped chest & 52 & $52 \%$ \\
\hline Rhonchi & 74 & $74 \%$ \\
\hline Crepitations & 94 & $94 \%$ \\
\hline CVS Pulmonary Hypertension & 32 & $32 \%$ \\
\hline \multicolumn{2}{|c|}{ Table 8: Systemic Examination } \\
\hline
\end{tabular}

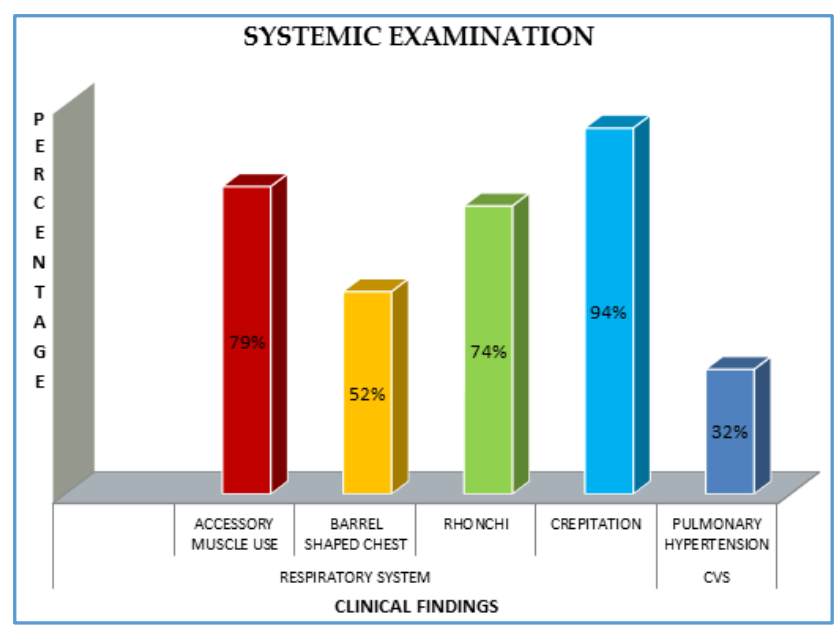

A $79 \%$ of patients had use of accessory muscles of respiration, $52 \%$ patients had barrel shaped chest, rhonchi was present in $74 \%$ patients, crepitations were heard in $94 \%$ patients and clinical signs of pulmonary hypertension were present only in $38 \%$ patients.

\begin{tabular}{|c|c|c|}
\hline Chest X-ray & $\begin{array}{c}\text { Number of } \\
\text { Patients }\end{array}$ & $\begin{array}{c}\text { Percentage } \\
\text { (\%) }\end{array}$ \\
\hline $\begin{array}{c}\text { Chronic } \\
\text { bronchitis }\end{array}$ & 49 & $49.0 \%$ \\
\hline Emphysema & 49 & $49.0 \%$ \\
\hline Normal & 2 & $2.0 \%$ \\
\hline Total & $\mathbf{1 0 0}$ & $\mathbf{1 0 0 . 0 \%}$ \\
\hline \multicolumn{3}{|c|}{ Table 9: Chest -ray } \\
\hline
\end{tabular}

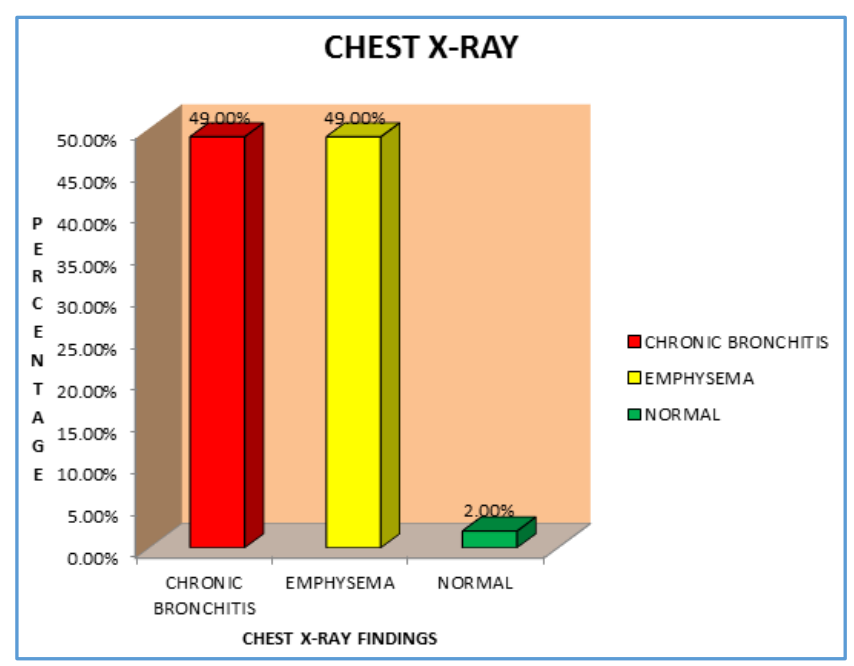

Graph 9: Chest X-ray
In the present study, $49 \%$ of patients had chronic bronchitis and emphysema on chest x-ray; $2 \%$ had normal chest x-ray.

\section{Pulmonary Function Tests}

\begin{tabular}{|c|c|c|c|}
\hline $\begin{array}{c}\text { Spirometric } \\
\text { Parameters }\end{array}$ & Range & Mean & SD \\
\hline FVC (lt) & $1.51-3.21$ & 2.36 & 0.43 \\
\hline FEV1 (lt) & $0.56-1.55$ & 1.07 & 0.24 \\
\hline FEV 1\% & $32.5-72.4$ & 45.79 & 10.29 \\
\hline FEV1/FVC & $30.7-68.0$ & 46.01 & 9.54 \\
\hline \multicolumn{4}{|c|}{ Table 10: Range and mean values of } \\
Spirometric Parameter \\
\hline
\end{tabular}

- $\quad$ FVC-reflects the change in vital capacity. The mean expected or predicted FVC was $3.0 \pm 0.45$ lit. The actual tested mean FVC is $2.36 \pm 0.43$ lit.

- FEV1-reflects the degree of airway obstruction. The mean expected or predicted FEV1 among the cases studied was $2.37 \pm 0.37$ lit. However, the actual tested mean FEV1 was $1.07 \pm 0.24$ lit.

- The mean FEV1\% in this study is $45.79 \pm 10.29 \%$.

- The mean FEV1/FVC \% ratio is $46.01 \pm 9.54$ in the present study.

\begin{tabular}{|c|c|c|}
\hline Stages & $\begin{array}{c}\text { Number of } \\
\text { Patients }\end{array}$ & $\begin{array}{c}\text { Percentage } \\
(\%)\end{array}$ \\
\hline $\begin{array}{c}\text { I-Mild : 60<FEV1 } \\
79 \% \text { predicted }\end{array}$ & 4 & $4.0 \%$ \\
\hline $\begin{array}{c}\text { II-Moderate }: 40 \% \\
\text { <FEV1 } 5 \text { 59\% } \\
\text { predicted }\end{array}$ & 46 & $46.0 \%$ \\
\hline $\begin{array}{c}\text { III-Severe : FEV1 }< \\
40 \% \text { predicted }\end{array}$ & 50 & $50.0 \%$ \\
\hline \multicolumn{2}{|c|}{ Table 11: Interpretation of Spirometry results } \\
\hline
\end{tabular}

Maximum number of patients in the present study were in stage III.

- $50 \%$ of the patients showing severe air flow obstruction.

- $46 \%$ of patients had moderate obstruction.

- $4 \%$ of patients had mild air flow obstruction.

\section{ECG Findings}

Of the 100 patients studied, heart rate was $86.64 \pm 9.65$.

\begin{tabular}{|c|c|c|}
\hline ECG Findings & $\begin{array}{c}\text { Number of } \\
\text { Patients }\end{array}$ & $\begin{array}{c}\text { Percentage } \\
\text { (\%) }\end{array}$ \\
\hline P Pulmonale & 51 & $51.00 \%$ \\
\hline Right axis deviation & 45 & $45.00 \%$ \\
\hline $\begin{array}{c}\text { Right ventricular } \\
\text { hypertrophy }\end{array}$ & 39 & $39.00 \%$ \\
\hline RBBB & 31 & $31.00 \%$ \\
\hline \multicolumn{2}{|c|}{ Table 12: ECG Findings } \\
\hline
\end{tabular}

Most common ECG abnormality found was P pulmonale, which was present in $51 \%$ of cases. Evidence of RVH, by any or all of 1) qR pattern with intrinsicoid deflection $>0.03 \mathrm{sec}$ in V1, 2) $R$ amplitude $<S$ amplitude in V5, 3) $R$ or $R$ l amplitude $<S$ amplitude in lead I, was found in $39 \%$ of patients. Other findings noted were incomplete RBBB (31\%), RAD (45\%) and RV strain (6\%). 


\section{ECHO Findings}

\begin{tabular}{|c|c|c|}
\hline ECHO Findings & $\begin{array}{c}\text { Number of } \\
\text { Patients }\end{array}$ & $\begin{array}{c}\text { Percentage } \\
\text { (\%) }\end{array}$ \\
\hline $\begin{array}{c}\text { Right ventricle dilatation } \\
\text { (RV EDD > 25mm) }\end{array}$ & 53 & $53.0 \%$ \\
\hline $\begin{array}{c}\text { Pulmonary hypertension } \\
\text { (PASP >30mmHg) }\end{array}$ & 53 & $53.0 \%$ \\
\hline $\begin{array}{c}\text { Right atrial enlargement } \\
\text { (RA diameter >3.6cm) }\end{array}$ & 42 & $42.0 \%$ \\
\hline $\begin{array}{c}\text { Right ventricle } \\
\text { hypertrophy (RV ant. } \\
\text { Wall >6mm) }\end{array}$ & 26 & $26.0 \%$ \\
\hline \multicolumn{2}{|c|}{ Table 13: ECHO Findings } \\
\hline
\end{tabular}

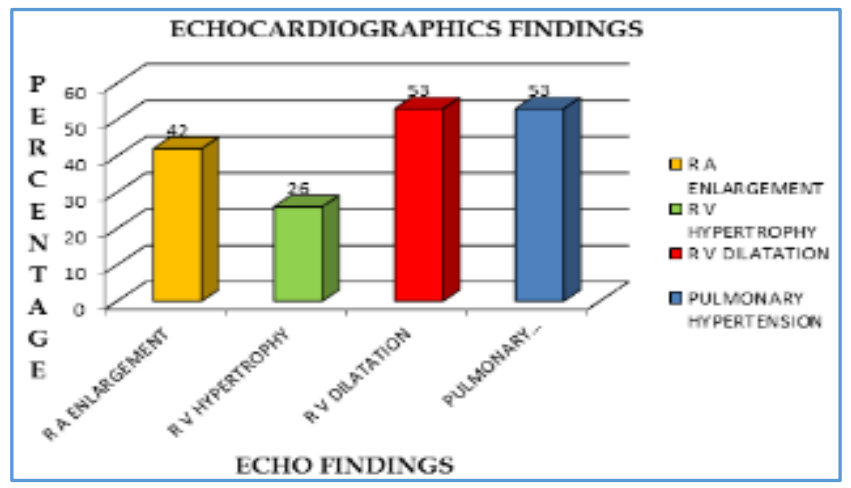

Graph 10: ECHO Findings

Right ventricle was dilated in 53\% patients.

Pulmonary artery systolic pressure $>30 \mathrm{~mm}$ of $\mathrm{Hg}$ (pulmonary hypertension) was present in $53 \%$ patients.

Right atrium enlargement was enlarged in $42 \%$ patients.

Right ventricle hypertrophy was seen in $26 \%$ patients.

\begin{tabular}{|c|c|c|c|c|c|c|c|c|}
\hline \multirow{3}{*}{ ECHO Findings } & \multirow{3}{*}{ Criteria } & \multicolumn{6}{|c|}{ Severity of COPD FEV1\% } & \multirow{3}{*}{$P$ value } \\
\hline & & \multicolumn{2}{|c|}{ Mild } & \multicolumn{2}{|c|}{ Moderate } & \multicolumn{2}{|c|}{ Severe } & \\
\hline & & $n=4$ & $\%$ & $n=46$ & $\%$ & $n=50$ & $\%$ & \\
\hline \multirow{2}{*}{$\begin{array}{c}\text { Right Atrium Enlargement (RA diameter } \\
>3.6 \mathrm{~cm}\end{array}$} & Present & 0 & $0 \%$ & 4 & $8.69 \%$ & 38 & $76.0 \%$ & \multirow[t]{2}{*}{$<0.01$} \\
\hline & Absent & 4 & $100 \%$ & 42 & $91.30 \%$ & 12 & $24.0 \%$ & \\
\hline \multirow{2}{*}{$\begin{array}{l}\text { Right Ventricle Hypertrophy (RV ant } \\
\text { wall }>6 \mathrm{~mm} \text { ) }\end{array}$} & Present & 0 & $0 \%$ & 0 & $0 \%$ & 26 & $52.0 \%$ & \multirow[t]{2}{*}{$<0.01$} \\
\hline & Absent & 4 & $100 \%$ & 46 & $100 \%$ & 24 & $48.0 \%$ & \\
\hline \multirow{2}{*}{$\begin{array}{l}\text { Right Ventricle Dilatation (RV EDD } \\
\qquad>25 \mathrm{~mm}\end{array}$} & Present & 0 & $0 \%$ & 15 & $32.60 \%$ & 38 & $76.0 \%$ & \multirow[t]{2}{*}{$<0.01$} \\
\hline & Absent & 4 & $100 \%$ & 31 & $67.39 \%$ & 12 & $24.0 \%$ & \\
\hline \multirow{2}{*}{$\begin{array}{l}\text { Pulmonary Hypertension( PASP } \\
>30 \mathrm{mmHg})\end{array}$} & Present & 0 & $0 \%$ & 15 & $32.60 \%$ & 38 & $76.0 \%$ & \multirow[t]{2}{*}{$<0.01$} \\
\hline & Absent & 4 & $100 \%$ & 31 & $67.39 \%$ & 12 & $24.0 \%$ & \\
\hline
\end{tabular}

The $P$ value is $<0.01$ and its significant.

In the mild group, there is no echocardiography evidence of right atrium enlargement, right ventricle hypertrophy, right ventricle dilatation and pulmonary hypertension.

In the moderate group, $32.60 \%$ (i.e. 15 out of 46 ) patients had right ventricle dilatation and pulmonary hypertension. Right atrium enlargement was seen in $8.69 \%$ patients.

In the severe group, $76 \%$ (i.e. 38 out of 50 ) patients had right atrium enlargement, right ventricle dilatation and pulmonary hypertension. Right ventricle hypertrophy was seen in $52.0 \%$ (i.e. 26 out of 50 ) patients.

The echo signs of right atrium enlargement, right ventricle hypertrophy, right ventricle dilatation and pulmonary hypertension correlated significantly with the severity of the COPD $(\mathrm{p}<0.01)$.

\section{DISCUSSION}

\section{Age Distribution}

The maximum numbers (79\%) of COPD patients in this study were in the age group of 51-70 years with mean age $61.84 \pm 8.63$ years, which is comparable to studies of Himelman. ${ }^{8}$ and Mohapatra PR et al. ${ }^{9}$ who found mean age as $66+6$ years and $60+9$ years respectively.

\section{Sex Distribution}

In this study, the Male:Female ratio was 6.14:1. Males form $86 \%(86 / 100)$ of the study subjects, which is comparable to Burrows et al. ${ }^{10}$ and V. K. Singh et al. ${ }^{11}$

\section{Place of Living}

In the present study, $83 \%$ subjects were from rural background, which was comparable to Goel S. et al. ${ }^{12}$ who reported $72.73 \%$ of patients from rural area.

\section{Severity of the Disease}

In the present study, $50 \%(50 / 100)$ of the patients had FEV1 $<40 \%$ of the predicted, i.e. severe obstructive disease. FEV1 \% less than $40 \%$ of the predicted in $50 \%$ of patient of the present study is comparable with $57.6 \%$ Higham et al. ${ }^{13}$ In the present study mean value FVC $2.36 \pm 0.43$, FEV1 $1.19 \pm 0.28$ and FEV1/FVC\% 52.66 \pm 11.33 , which is comparable to Kamat SR et al. ${ }^{14}$ study group.

5. Clinical Symptoms: In the present study, cough was present in $97 \%$, expectoration in $93 \%$ patients followed by breathlessness in $91 \%$ patients.

6. Smoking History: $89 \%$ of patients in the study group were smokers and $76 \%$ had smoking history of more than 20 pack years. Findings of smoking status was comparable to Prasanta R Mohapatra et al. ${ }^{9}$

\section{Physical Examination}

In the present series cyanosis is $43 \%$, barrel shaped chest in $52 \%$ and ronchi in $74 \%$ are comparable with Gupta S et al. ${ }^{15}$ In this study, Jugular venous pressure was raised in $56 \%$ and pedal oedema in $65 \%$ is comparable with studied patients of Padmavati. ${ }^{16}$ 


\section{Chest X-ray}

Chest $x$-ray findings showed chronic bronchitis in $49 \%$ and emphysema in $49 \%$, because in the present series only the COPD patients were included.

\section{Electrocardiography}

ECG evidence of P-pulmonale in 51\%, right axis deviation in $45 \%$ and $\mathrm{RVH}$ in $39 \%$ of patient is comparable with findng of S. Gupta et al. 15

\section{Echocardiography}

In the present study Echo studies show RV dilatation in 53\%, Pulmonary hypertension in 53\%, RA enlargement in $42 \%$ and RV hypertrophy in $26 \%$ are comparable with study of Himelmann et al. ${ }^{8}$ who found RV dilatation in 55\%, pulmonary hypertension in $49 \%$, RA enlargement in $39 \%$ and RV hypertrophy in $25 \%$.

The classical view of the development of heart failure in patients with COPD is that hypoxia leads to pulmonary hypertension which imposes increased work in the right ventricle leading to right ventricular hypertrophy and eventually RV dilatation and then RV failure. The RA dilatation is a consequence of systolic overload on RA due to RV hypertrophy.

In the present study, the incidence of all the echocardiographic findings increased as the severity of the disease increased, i.e. maximum incidence was found in the most severely affected group of patients.

\begin{tabular}{|c|c|c|}
\hline Echo Findings & $\begin{array}{c}\text { Moderate } \\
\text { COPD }\end{array}$ & $\begin{array}{c}\text { Severe } \\
\text { COPD }\end{array}$ \\
\hline $\begin{array}{c}\text { RA Enlargement.(RA diameter }>3.6 \\
\mathrm{~cm} \text { ) }\end{array}$ & $8.69 \%$ & $76.0 \%$ \\
\hline RV Dilatation(RV EDD $>25 \mathrm{~mm}$ ) & $32.60 \%$ & $76.0 \%$ \\
\hline $\begin{array}{c}\text { RV Hypertrophy (RV anterior wall } \\
\text { thickness }>6 \mathrm{~mm} \text { ) }\end{array}$ & $0.0 \%$ & $52.0 \%$ \\
\hline $\begin{array}{c}\text { Pulmonary Hypertension } \\
\text { (PASP }>30 \mathrm{mmHg})\end{array}$ & $32.60 \%$ & $76.0 \%$ \\
\hline
\end{tabular}

The incidence in the moderate and the severe groups are found to be fairly correlating.

Comparison of pulmonary hypertension with other studies

\begin{tabular}{|c|c|c|}
\hline Severity & Higham et al. $^{\mathbf{1 3}}$ & Present Study \\
\hline Moderate & $(\mathrm{n}=12) 25 \%$ & $(\mathrm{n}=15) 32.60 \%$ \\
\hline Severe & $(\mathrm{n}=42) 68 \%$ & $(\mathrm{n}=38) 76.0 \%$ \\
\hline
\end{tabular}

In our study, $53 \%$ of patients have ECHO evidence of pulmonary artery hypertension and right ventricle dilatation; $42 \%$ patients had right arterial dilatation and $26 \%$ patient had right ventricle hypertrophy. Both right atrial enlargement and right ventricle hypertrophy show poor prognosis; $32.60 \%$ of moderate COPD and $76.0 \%$ of severe COPD respectively had pulmonary hypertension and right ventricle dilatation respectively, which affect the mortality and morbidity of the patients. So echocardiography is an important tool in early diagnosis of RV dysfunction.

\section{SUMMARY}

In the series of 100 cases of COPD $86 \%$ were male with maximum number of patients in the age group between 61 to 70 years and majority of them $89 \%$ were smoker and $64 \%$ were farmers from rural background, 83\% Chronic cough, expectoration of sputum, dyspnoea and swelling of the feet were the common symptoms. Diminished chest movement, crepitations, rhonchi and cyanosis were the common signs. A $50 \%$ of the patients had severe airway obstruction (FEV1 less than $40 \%$ ). ECG showed P-pulmonale in 51\%, right axis deviation in 45\%, RVH in 39\% and RBBB in 31\%.

Echocardiography detected pulmonary hypertension in $53 \%$, dilated right ventricle in 53\%, right atrial enlargement in $42 \%$ and hypertrophy in $26 \%$. A significant correlation was found between severity of COPD and echocardiographic findings.

\section{CONCLUSION}

From the present study it is concluded that COPD is fairly common in male smoker in the age group 61 years to 70 years, who are rural dwellers and farmers. Chronic cough, expectoration, dyspnoea are common symptoms. Spirometry is sensitive in diagnosing and assessing the severity. ECG and echocardiography helps in detection of cardiac involvement, particularly involvment of right side of heart in COPD patients. Echocardiographic findings also correlate with the severity of COPD and should be done in all cases of chronic obstructive pulmonary disease.

\section{BIBLIOGRAPHY}

1. World Health Report. Geneva: World Health Organization. Available from URL: http://www.who.int/whr/2000/en/statistics.htm; 2000.

2. Klinger JR, Hill NS Right ventricular dysfunction in chronic obstructive pulmonary disease, evaluation and management. Chest 1991;99:715-23.

3. Harvey RM, Ferrer IM, Richards Jr DW, Cournand A. Influence of chronic pulmonary disease on the heart and circulation. American journal of medicine 1951;10:719.

4. Hirschfeld S, Meyer R, Schwartz DC, et al. The echocardiographic assessment of pulmonary artery pressure and pulmonary vascular resistance Circulation 1975;52:642-649.

5. Watanabe T, Katsume H, Matsukubo H, et al. Estimation of right ventricular volume with two dimensional echocardiography. The American journal of cardiology 1982;49:1946-1953.

6. Starling MR, Crawford MH, Sorensen SG, et al. A new two dimensional echocardiographic technique for evaluating right ventricular size and performance in patients with obstructive lung disease Circulation 1982;66:612-20.

7. Oswald Mammosser M, Oswald T, Nyankiye E, et al. Noninvasive diagnosis of pulmonary hypertension in chronic obstructive pulmonary disease comparison of ECG, radiological measurements, echocardiography and myocardial scintigraphy. Eur J Respir Dis 1987;71(5):419-29.

8. Himelmann RB, Struve SN, Brown JK, et al. Improved recognition of cor pulmonale in patients with severe chronic obstructive pulmonary disease Am J Med 1988;84:891-898.

9. Mohapatra PR, Janmeja AK. Factors associated with hospital admission in patients with acute exacerbation of COPD. CHEST 2011;52:203-6.

10. Burrows B, Kettel LJ, Niden AH, et al. Patterns of Cardiovascular dysfunction in chronic obstructive lung disease. N Engl J Med 1972;286(17):912-917. 
11. Singh VK and Jain SK. Effects of airflow limitation on the electrocardiogram in COPD Indian Journal of chest diseases and Allied sciences 1989;31(1):1-8.

12. Goel S, Gupta BP, Kashyap S, et al. Epidemiological aspects of chronic bronchitis in Shimla Hills Indian Journal of Chest Diseases \& Allied Sciences 2007; Vol. 49:143-147.

13. Higham MA, Dawson D, Joshi J, et al. Utility of echocardiography in assessment of pulmonary hypertension secondary to COPD Eur. Respir J 2001;17:350-355.
14. Kamat SR, Doshi VB, Mahashur AA, Gregrat JK, Natu RB, Patade VD, et al. Behavior on follow-up in chronic obstructive pulmonary disease Lung India. 1984;2(1):76-83.

15. Gupta S, Khastgir T, Gupta MP, et al. Clinical, haemodynamic and echocardiographic study in chronic cor pulmonale J Assoc Physicians India 1989;37:373-376.

16. Padmavati S, Pathak SN. Chronic cor pulmonale in Delhi: A study of 127 cases Circulation 1959;20:343-352. 